\title{
Antibiotik Pemicu Fotosensitivitas Obat yang Harus Diketahui Apoteker
}

Hafshah Nurul Afifah

PT. Cendo Pharmac eutic al Industries, Bandung, Jawa Barat, Indonesia

Terbit online : 28 Agus tus 2016

\section{Abstrak :}

Reaksi fotosensitivitas merupakan efek samping yang umum terjadi dari banyak obat, melputi agen-agen antimikroba, obat-obat anti-inflamasi non-steroid, diuretik, dan kemoterapetik. Obat yang dapat menimbulkan reaksi fotosensitivitas dapat berupa obat bersifat sistemik ataupun topikal. Area tubuh yang paling sering mengalami reaksi fotosensitivitas adalah area yang sering terpapar cahaya, seperti wajah, area tengkuk, kaki bagian depan, dan lengan bagian belakang. Obat antibiotik yang menimbulkan fotosensitivitas diantaranya fluorokuinolon, turunan tetrasiklin, turunan sulfonamid. Apoteker harus mampu memberikan konseling yang benar pada pasien mengenai penggunaan antibiotik-antibiotik tersebut.

Keyword : antibiotik, fotosensitivitas, apoteker

\section{Pendahuluan}

Reaksi fotosensitivitas merupakan efek samping yang umum terjadi dari banyak obat, melputi agen-agen antimikroba, obat-obat anti-inflamasi non-steroid, diuretik, dan kemoterapetik. Faktanya, sekitar $8 \%$ reaksi samping dermatologik dikaitkan dengan efek fotosensitisasi dari obat.

Beberapa bahan yang membuat peka terhadap sinar matahari :

\section{Obat antiansietas}

Alprazolam

Chlordiazepoxide

\section{Antidepresan}

antidepresan trisiklik

\section{Obat antijamur (yang diminum)}

Griseofulvin

\section{Antihiperglikemik}

Sulfonilurea

\section{Obat antimalaria}

Kloroquin

Kuinin

\section{Antipsikotik}


Diuretik

Furosemid

Tiazid

\section{Obat Kemoterapi}

Dacarbazin

Fluorouracil

Methotrexate

Vinblastin

\section{Obat jantung}

Amiodarone

Kuinidin

\section{Obat kulit}

Antibakteri (chlorhexidine, hexachlorophene)

Obat antijamur

Ter

Pewangi

Tabir surya

Karena antibiotik yang menyebabkan fotosensitivitas banyak digunakan dalam praktik klinis, apoteker harus mengetahui potensi fotosensitivitas saat memberikan obat dan melakukan konseling pada pasien yang mengonsumsi obat-obatini.

\section{Fototoksisitas atau Fotoalergi?}

Fotosensitivitas karena obat merupakan respon kulit terhadap interaksi antara bahan kimia (obat) dan bahan fisik (cahaya). Bahan kimia yang dapat menimbulkan reaksi fotosensitivitas dapat berupa bahan sistemik ataupun bahan topikal. Obat ini merupakan senyawa di-trisiklik, dengan berat molekul $300-500 \mathrm{gm} / \mathrm{mol}$.

Spektrum kerja obat ini adalah spektrum radiasi yang dibutuhkan oleh fotosensitizer karena obat ini berbeda, yakni reaksi fototoksik dan reaksi fotoalergi. Dibutuhkan pemeriksaan dan anamnesa yang teliti untuk dapat menegakkan diagnosis.

Meskipun kedua subkategori fotosensitivitas ini mungkin sulit dibedakan karena manifestasi klinis yang serupa, terdapat beberapa perbedaan yang dapat terlihat.

Reaksi fototoksisitas dapat terjadi pada setiap pasien yang mengonsumsi sejumlah obat tertentu dan terpapar cahaya dalam jumlah tertentu yang dapat menimbulkan reaksi. Dibandingkan dengan reaksi fotoalergi, fototoksisitas membutuhkan dosis obat yang lebih tinggi untuk terjadinya reaksi dan dapat muncul pada paparan obat pertama kali. Reaksi fototoksik yang banyak terjadi yaitu sengatan matahari (sunbum) pada area kulit yang terbuka, yang kemudian mengalami hiperpigmentasi.

Reaksi fotoalergi lebih jarang terjadi dibandingkan reaksi fototoksik dan dihasilkan oleh imunitas yang dimediasi-sel. Seperti reaksi alergi lainnya, reaksi fotoalergi tidak muncul pada saat paparan obat pertama kali sehingga membutuhkan sensitisasi.

Tidak seperti fototoksisitas, reaksi fotoalergi hanya membutuhkan sejumlah kecil agen pemicu dan kemunculannya dapat tertunda selama beberapa hari setelah paparan terhadap cahaya dan obat. Secara klinis, reaksi ini menyerupai eksim dan dapat menyebar ke area kulit yang fodak terpapar oleh cahaya. 
Area tubuh yang paling sering mengalami reaksi fotosensitivitas adalah area yang sering terpapar cahaya, seperti wajah, area tengkuk, kaki bagian depan, dan lengan bagian belakang. Reaksi ini biasanya menyerupai sengatan matahari parah disertai edema dan eritema. Pada kasus yang parah, dapat terbentuk lepuhan dan pasien akan mengeluhkan kulit terbakar, kulit lunak melepuh, dan nyeri. Hiperpigmentasi, yang merupakan hasil dari proliferasi atau deposisi melanosit akibat obat dan fotoproduknya, mungkin tidak akan hilang meski fase akut reaksi telah terlewati.

Manifestasi fotosensitivitas lain di antaranya:

-Foto-onikolisis: Terlepasnya kuku dari dasar kuku setelah paparan terhadap radiasi ultraviolet. Gejala ini terjadi paling sering akibat penggunaan tetrasiklin.

-Pseudoporfiria: Ditandai oleh lepuhan, kerapuhan kulit, lukagores, dan mudah lebam. Gejala ini dikaitkan dengan penggunaan tetrasiklin dan dapsone, pulih setelah penghentian obat pemicu reaksi.

\section{Antibiotik yang Diketahui Menyebabkan Fotosensitivitas}

\section{Fluorokuinolon}

Antibiotik ini menyebabkan fotosensitivitas dengan derajat yang bervariasi, sebagian besar menyebabkan reaksi fototoksik. Potensi fotosensitivitas meningkat dengan halogenas pada posisi C-8 dan pada senyawa dengan waktu-paruh dan bioavailabilitas yang lebih lama. Sebaliknya, moxifloxacin dan gatifloxaci memiliki gugus metoksi pada posisi ini sehingga memiliki fotostabilitas yang paling baik. Levofloxacin dan ciprofloxacin, dua senyawa florokuinolon yang paling banyak digunakan saat ini, memiliki potensi fototoksil yang relatif rendah.

\section{Turunan Tetrasiklin}

Antibiotik ini sangat terkenal menyebabkan reaksi fototoksik. Manifestasi klinisnya meliputi sengatan matahari dan erupsi, diikuti dengan hiperpigmentasi residual. Selain itu, fotoonikolisis juga sering kali ditemukan, muncul beberapa minggu setelah paparan terhadap obat dan menyerang bagian distal pada satu kuku atau lebih. Perubahan warna kuku juga dapat terjadi.

Dari semua senyawa tetrasiklin, doksisiklin adalah sensitizer yang paling sering menyebabkan reaksi ini. Dosis dan intensitas UV-A menjadi penentu potensi fototoksik yang paling utama. Tetrasiklin menyebabkan pseudoporfiria. Minosiklin memilik potensi yang rendah untuk menyebabkan fototoksisitas, tetapi dilaporkan terjadi fotoonikolisis.

\section{Turunan Sulfonamid}

Tidak seperti tetrasiklin dan fluorokuinolon yang utamanya melibatkan rentang UVA, fotosensitivitas akibat obat-obat sulfonamid muncul pada rentang cahaya UV-B. Meskipun antibiotik sulfonamid aman dalam hal fotosensitivitas, diuretik yang mengandung sulfur dan obatobat diabetes merupakan pemicu yang umum.

Sulfametoksazol, suatu komponen antibiotik kotrimoksazol yang banyak digunakan, terbukt menyebabkan fototoksisitas, begitu juga dapsone. Sulfasalazin, yang digunakan untuk artritis reumatoid, menyebabkan hiperpigmentasi pada kulit yang terpapar cahaya. 


\section{Informasi yang Harus Diberikan pada Pasien}

Saat memberikan konseling pada pasien mengenai penggunaan antibiotik-antibiotik tersebut, tekankan untuk menghindari sinar matahari langsung atau sengaja berjemur. Jika menghindari sinar matahari tidak memungkinkan, sarankan untuk menggunakan pakaian tertutup dan menggunakan tabir surya spektrum luas dengan SPF setidaknya 30. Kompres dingin dan kortikosteroid topikal dapat direkomendasikan untuk sengatan matahari ringan, tetapi pasien harus berobatke dokter jika reaksinya parah.

Daftar Pustaka:

http://www.pharmacytimes.com/contributor/thomas-szymanski-pharmd-candidate2017/2016/08/druq-induced-photosensitivity-focus-on-antibiotics/P-1. Diakses pada 28 Agustus 2016.

http://penelitian.unair.ac.id/artikel dosen Fotosensitivitas\%20karena\%20Obatobatan 42233767 . Diakses pada 28 Agustus 2016.

http://sehat-enak.blogspot.com/2010/02/reaksi-fotosensitivitas.html. Diakses pada 28 Agustus 2016. 